\title{
Problematyka globalizacji dzialalności sektora bankowego w edukacji szkolnej
}

W procesie nauczania podstaw przedsiębiorczości i innych przedmiotów ekonomicznych istotne znaczenie ma problematyka funkcjonowania sektora bankowego, który w ostatnich latach podlega nieustannym i szybkim zmianom. Celem niniejszego artykułu jest przedstawienie procesów globalizacji działalności sektora bankowego, co może być pomocne w prowadzeniu lekcji na ten temat.

\section{Globalizacja rynków kapitałowych a bankowość}

Wzrost zależności między ogniwami światowego rynku finansowo-kapitałowego powoduje, że rola banków nieustannie się zmienia. Zależności te mają coraz częściej charakter globalny i nie mogą być rozpatrywane tylko w skali narodowej czy regionalnej. Postęp w komputeryzacji i telekomunikacji przyczynia się do powszechnej globalizacji sektora bankowego oraz konsolidacji banków. Nowe możliwości działania banków są wynikiem zmian w skali światowej na rynku kapitałowym w zakresie ${ }^{1}$ :

- liberalizacji przepływu kapitałów i usług;

- unifikacji i standaryzacji rynków kapitałowych;

- globalizacji systemu informacji;

- powstania unii monetarnej oraz rozwoju funduszy inwestycyjnych i emerytalnych oraz towarzystw ubezpieczeniowych, a także rozwoju usług bankowości inwestycyjnej;

- powstania nowych wyspecjalizowanych instrumentów finansowych;

- wzrostu konkurencji między rynkami kapitałowymi.

Liberalizacja przepływu kapitału i usług dotyczy emisji papierów wartościowych i ich obrotu między rynkami różnych krajów oraz swobodnego świadczenia usług w zakresie działalności maklerskiej i doradztwa ds. inwestowania w papiery wartościowe. Celem standaryzacji i unifikacji jest usprawnienie przedsięwzięć (rozwiązania techniczno-organizacyjne, regulacyjno-prawne) inwestorów w zakresie ponadnarodowych transakcji finansowych. Jest to możliwe dzięki wykorzystaniu nowoczesnych technik komputerowych przez banki i giełdy. Powoduje to, że ich usługi upodabniają się do siebie. Globalizacja systemu informacji wynika głównie ze wzrostu dostępności informacji i swobodnego jej przepływu. Wzrost szybkości przepływu informacji na rynkach finansowych nastąpił dzięki postępowi techniczno-technologicznemu oraz rozwojowi systemów informatycznych. Powstanie unii monetarnej, rozwój funduszy inwestycyjnych i emerytalnych oraz towarzystw ubezpieczeniowych powoduje rozwój usług bankowości inwestycyjnej. Funkcjonowanie waluty euro sprzyja konsolidacji rynków finansowych, w tym banków. Globalizacja

\footnotetext{
${ }^{1}$ A. Janc, Sektor bankowy w procesie zmian bankowych, AE, Poznań 1997.
} 
rynku kapitałowego stwarza warunki swobodnego przepływu kapitału i papierów wartościowych. Emitenci papierów wartościowych mogą za pośrednictwem banków szukać kapitału na zagranicznych rynkach kapitałowych. Globalizacja gospodarki i rynków finansowych daje szansę inwestowania w papiery wartościowe na tych rynkach.

Największe zainteresowanie budzi rozwinięty rynek kapitałowy Stanów Zjednoczonych, gdzie powstała koncepcja amerykańskich kwitów depozytowych, tzw. ADR-ów (American Depositary Receipt), emitowanych przez banki. Również w Europie, na wzór amerykańskich, wprowadzono kwity depozytowe, tzw. GDR-y (Global Depositary Receipt), szczególnie w Londynie i Luksemburgu.

Na rynkach finansowych następuje przejście z fazy przewagi banków komercyjnych do wiodącej roli banków inwestycyjnych, a w konsekwencji do sekurytyzacji. Termin ten oznacza przewagę na rynkach finansowych instytucji spełniających rolę alokacji oszczędności oraz ich transformacji, a także monitoringu i controllingu. Sekurytyzacja to możliwość upłynniania, w formie papierów wartościowych, aktywów banku, które utraciły swoją płynność, np. utracone dla banku kredyty. Wszystkie zmiany determinujące globalizację działalności banków mają wpływ na stopień ich konkurencyjności. Dlatego też banki muszą szukać nowych obszarów działalności inwestycyjnej.

\section{Globalizacja produktów i usług bankowych}

Dzięki rozwojowi technologii informatycznych i telekomunikacyjnych, przede wszystkim internetu i telefonii komórkowej, zapewniono dostęp do banku przez całą dobę, przez cały rok, z dowolnego miejsca na kuli ziemskiej. Stanowi to dla banków wyzwanie, gdyż z - jednej strony - stwarza szansę na dodatkowe zyski, ale - z drugiej strony - wymaga poszerzenia kanałów dostępu do produktów i usług bankowych. Usługi bankowości elektronicznej oferują już wszystkie banki komercyjne w Polsce.

Oprócz bankowości internetowej najbardziej rozwojową formę bankowości elektronicznej stanowi bankowość mobilna. Jest to ogół form elektronicznych usług bankowych związanych z wykorzystaniem urządzeń i technologii mobilnych w procesie obsługi klienta. Najbardziej perspektywicznym narzędziem mobilnych usług bankowych wydaje się być telefonia komórkowa. Telefon komórkowy jest jedynym, oprócz komputera osobistego, narzędziem ułatwiającym dostęp do zasobów internetu. Za pomocą telefonu komórkowego można korzystać z następujących usług bankowych:

- SMS - za pomocą wiadomości SMS bank może powiadomić klienta o stanie konta, naliczonych odsetkach, o przekroczeniu dopuszczalnego limitu kredytowego, a także o nowej ofercie usług bankowych. Klient może przesłać do banku pytanie o stan konta, założyć lokatę terminową i złożyć polecenie przelewu. Zaletą tej usługi jest jej prostota, ale korzystanie z niej jest czasochłonne i bardzo ograniczone. Nie jest możliwe przesłanie za pomocą SMS zestawienia transakcji klienta, tabeli kursów walut i pełnej oferty lokat terminowych.

- MMS - ograniczenia SMS są wyeliminowane w usłudze MMS. Ich najbardziej charakterystyczną cechą jest pełna multimedialność, tzn. możliwość zawarcia w wiadomości dźwięków, animacji i filmów. MMS mają zastosowanie w bankowości mobilnej jako kanały dystrybucji materiałów marketingowych, reklam, a także infoserwisów z kursami walut, wiadomościami z giełd, prognozami gospodarczymi itp.

- Poczta elektroniczna - usługa poczty elektronicznej w telefonach komórkowych to przeniesienie klasycznej internetowej usługi poczty elektronicznej w świat telefonii mobilnej. Dzięki temu telefon komórkowy staje się narzędziem zdalnego dostępu do elektronicznej skrzynki pocztowej klienta, uniezależniając go od dostępności połączenia internetowego i komputera osobistego. Pocztą elektroniczną można złożyć wniosek kredytowy. 
- WAP - usługa daje możliwość przeglądania za pomocą telefonu uproszczonych serwisów internetowych. Dostęp do informacji, podobnie jak w przypadku stron www, odbywa się przez wprowadzenie odpowiedniego adresu i nawigowanie po kolejnych stronach prezentujących dane lub oferujących usługi katalogowe. Dzięki przeglądarce WAP klient ma dostęp do elektronicznego oddziału swojego banku, gdzie może wykonywać wszystkie operacje na swoim koncie. Jedyną barierą w rozpowszechnianiu usług WAP jest ich wysoki koszt.

- Call-center - operacje bankowe z udziałem call-center mogą być wykonywane na dwa sposoby, automatycznie lub z udziałem operatora. Automatyczne wykonywanie operacji za pomocą call-center polega na wyborze za pomocą klawiatury telefonu numerów odpowiadających poszczególnym operacjom. Ich liczba jest zwykle ograniczona do sprawdzenia stanu konta, założenia lokaty lub dokonania przelewu.

Bardziej skomplikowane operacje, takie jak: przelewy na dowolny rachunek, zmiana danych właściciela rachunku, złożenie reklamacji, odbywają się z udziałem operatora. Większość operacji wymaga jednak podania hasła lub odpowiedzi na wcześniej ustalone pytania.

\section{Zarządzanie globalne}

Wraz z pojęciem globalizacji pojawia się pojęcie banku globalnego (globalnej instytucji finansowej) oraz zarządzania globalnego. Zgodnie z definicją Giffina, bankiem globalnym jest bank, którego działalność wykracza poza granice jednego państwa. Niektóre grupy finansowe, jak Citibank i Deutsche Bank, mają centralę w jednym kraju, lecz określa się je jako globalne instytucje bankowe.

Zarządzanie globalne definiuje się jako zarządzanie skoncentrowane na identyfikacji i wykorzystaniu szans pojawiających się na światowym rynku oraz minimalizacji zagrożeń, obejmujących świadczenie usług na skalę światową, a także globalny marketing.

Podstawowymi cechami zarządzania globalnego są:

- globalna kooperacja - banki rozwijają na arenie międzynarodowej wspólną strategię, wykorzystują wspólnie swoje mocne strony;

- zarządzanie dynamiczne - szybkie kreowanie nowych usług i produktów;

- struktury globalne - rozbudowane struktury organizacyjne, wielowymiarowe, mające wspólną bazę danych, jednolite procedury i zintegrowaną logistykę.

Każdy menedżer banku pragnący skutecznie działać na rynku międzynarodowym musi łączyć działania lokalne z myśleniem globalnym. Pewnymi dziedzinami zarządza się globalnie, na poziomie centrali, np. zarządzanie ryzykiem, rentownością, portfelem produktów i usług, innymi zaś lokalnie, np. zasobami ludzkimi, relacjami z klientami. Lokalny zarząd godzi więc ze sobą cel i strategię całej grupy oraz oczekiwania i specyfikę rynku lokalnego.

\section{Controlling w banku globalnym}

Controlling jest systemem wspierającym koordynacyjnie i informacyjnie zarządzanie. Jego celem jest podnoszenie efektywności zarządzania oraz wzmacnianie zdolności dostosowawczych systemu zarządzania do zmian zachodzących wewnątrz i w otoczeniu banku. Do podstawowych zadań controllingu należy wspieranie kierownictwa banku przy formułowaniu wszystkich celów cząstkowych działań banku oraz koordynacja pojedynczych czynności i obszarów działania banku ze względu na te cele. Podstawą dobrze zorganizowanego systemu controllingu jest sprawnie działający system planowania i kontroli oraz system informacji, ułatwiające zarządzanie bankiem. Globalizacja systemu bankowego wiąże się nie tylko z otwieraniem 
nowych oddziałów i rozszerzaniem działalności na inne kraje, ale również z fuzjami i przejęciami banków działających w różnych krajach. Obecność na wielu rynkach oznacza konieczność rozwiązania różnych problemów wynikających z:

- różnych systemów przetwarzania danych,

- zróżnicowanych struktur danych,

- innych zasad rachunkowości i przepisów prawnych,

- różnych walut,

- zróżnicowanego ryzyka krajów,

- współpracy z ludźmi różniącymi się pod względem stylów działania i przyzwyczajeń.

Na przykład controller w Stanach Zjednoczonych i Wielkiej Brytanii wykonuje inne zadania niż w pozostałych krajach europejskich. W Stanach Zjednoczonych w centrum zainteresowania controllingu znajduje się rachunkowość, zarówno zarządcza, jak i finansowa, a w Niemczech controlling ogranicza się do rachunkowości zarządczej. W związku z coraz większym zasięgiem terytorialnym działania banków, zadania controllingu rozwijają się w kierunku międzynarodowych powiązań i obejmują często zmiany kursów walut oraz konsolidacje instytucji finansowych o zasięgu międzynarodowym. Wysoki stopień decentralizacji zarządzania oraz rozbudowane struktury organizacyjne grup globalnych powodują, że istotne do ich funkcjonowania jest zapewnienie skutecznej kontroli oraz nadzoru.

\section{Formy konsolidacji banków}

Z procesem globalizacji ściśle wiążą się zachodzące z dużą intensywnością procesy konsolidacji, których celem jest stworzenie większych podmiotów, mogących łatwiej sprostać zaostrzonej konkurencji na rynkach krajowych i zagranicznych. Konsolidacja banków może być realizowana przez: fuzję banków, przejęcie banków, zakup kluczowego pakietu akcji, bankowe grupy kapitałowe, konglomeraty finansowe.

- Fuzja banków to połączenie banków w wyniku porozumienia, którego celami są: umocnienie pozycji na rynku, skuteczniejsze przeciwdziałanie konkurencji lub podjęcie wspólnej ekspansji na określonych rynkach. W wyniku fuzji miejsce połączonych jednostek zajmuje nowy podmiot.

- Przejęcie banków (wchłonięcie) to przejęcie jednego banku, zwykle znajdującego się w trudnej sytuacji finansowej, przez inny bank, będący w dobrej kondycji i posiadający odpowiednio duże zasoby kapitałowe. W wyniku tej operacji bank przejmujący zobowiązuje się rozwiązać problemy finansowe banku przejmowanego. Przejęcie może nastąpić z pełną aprobatą jednostki przejmowanej, która traci samodzielność, ale unika bankructwa i upadłości. Może też mieć charakter jednostronnej decyzji poprzez wykupienie akcji przejmowanego banku od ich dotychczasowych posiadaczy.

- Zakup kluczowego pakietu akcji - zakup dotyczy banku będącego w dobrej sytuacji finansowej, o ugruntowanej pozycji rynkowej. Bank ten staje się najczęściej filią banku, który zakupił kluczowy pakiet akcji. Nabywca steruje działalnością jednostki, wybiera radę nadzorczą i zarząd. Jednostka staje się składnikiem większego skonsolidowanego organizmu, utworzonego przez nabywcę akcji.

- Bankowe grupy kapitałowe - tego rodzaju konstrukcja wiąże ze sobą kilka banków, które na mocy zawartej dobrowolnie umowy podejmują stałą współpracę i koordynują swoje działania, tworząc między sobą powiązania kapitałowe. Wszystkie banki należące do grupy zobowiązują się zapewnić płynność płatniczą każdego z pozostałych w przypadku powstania trudności płatniczych jednego z nich. Odmianą bankowej grupy kapitałowej jest holding, w którym zamiast banku dominującego występuje spółka holdingowa.

- Konglomeraty finansowe są to grupy bankowo-ubezpieczeniowe oferujące produkty bankowe i ubezpieczeniowe. Działalności bankowa i ubezpieczeniowa przynoszą korzyści obu stronom. 


\section{Podsumowanie i wnioski}

1. Banki stanowią główny, dominujący i najlepiej rozwinięty segment rynku finansowego.

2. Systemy bankowe charakteryzuje duży udział zagranicznych właścicieli.

3. W poszczególnych krajach występuje różny stopień konsolidacji na rynku bankowym.

4. Pozycję banków na rynkach zagranicznych umacniają różne formy konsolidacji.

5. Szybki rozwój technologii informatycznych i telekomunikacyjnych stwarza bankom możliwości oferowania atrakcyjnych usług.

6. Coraz ostrzejsza konkurencja między instytucjami finansowymi, będąca efektem liberalizacji rynków finansowych, wymusza rozszerzanie działalności banków na skalę międzynarodową.

W miarę postępu globalizacji coraz większego znaczenia nabierają instytucje rynku finansowego, dobrze rozwinięte w krajach stosujących anglo-amerykański model systemu finansowego. Model ten cechuje się większą niż inne innowacyjnością. Jest on bardziej otwarty; sprzyja umiędzynarodowieniu transakcji oraz swobodnemu przepływowi kapitału pomiędzy poszczególnymi regionami świata.

O globalizacji rynków finansowych mówi się w kontekście szybkich przepływów finansowych pomiędzy rynkami finansowymi różnych krajów świata. Proces globalizacji tych rynków trwa nieustannie od końca II wojny światowej. Termin ten obejmuje zmiany ilościowe oraz jakościowe w kierunku umiędzynarodowienia rynków. Jest on możliwy dzięki dynamicznemu postępowi technicznemu. Ograniczenie w przepływie kapitału oraz możliwość zawierania transakcji finansowych nawet między najbardziej odległymi rynkami świata powoduje stopniowy zanik granic pomiędzy tymi rynkami. Stosowanie nowoczesnych rozwiązań informatycznych i telekomunikacyjnych umożliwia wycenę i obrót skomplikowanymi instrumentami finansowymi na świecie. Dla procesu globalizacji systemu bankowego kluczowe znaczenie ma możliwość wykorzystania tych rozwiązań do zarządzania wielką liczbą transakcji dokonywanych na wszystkich kontynentach. Bez nowoczesnych technologii w bankowości proces globalizacji nie następowałby w tak szybkim tempie.

\section{Literatura}

1. Bankowość wobec procesów globalizacji, Uniwersytet Gdański, Katedra Finansów, Gdańsk 2003.

2. Budnikowski A., Międzynarodowe stosunki gospodarcze, PWE, Warszawa 2003.

3. Czarny E. (red.), Globalizacja A-Z, NBP, Warszawa 2004.

4. Dobosiewicz Z., Wprowadzenie do finansów i bankowości, PWN, Warszawa 2000.

5. Janc A., Sektor bankowy w procesie zmian bankowych, AE, Poznań 1997.

6. Rynki finansowe wobec procesów globalizacji, Uniwersytet Gdański, Katedra Finansów, Gdańsk 2003.

\section{Matters of Globalization in Banking Industry as an Element of School Education}

In the era when economy is acquiring more international character, the world market, so far a collection of national and international markets, is becoming a global market of particular products. Individual countries are becoming less important, whereas international companies 
are gaining more significance, being more difficult to control including the control of the national public authorities. Globalisation, understood as a progressing internalisation of economic activity or as a closer uniting of national economies, consists of various and complex processes and issues. The development of globalisation is influenced by various factors: the growing mobility of the capital, goods and services, technological progress, especially quick introduction of all the innovations, considerable reductions of the prices of transport and communication. Owing to the computer revolution, the borders between the countries stop to be an obstacle to the transfer of the goods and production factors, especially of the financial capital. The transfer can be done directly by the financial institutions or through their officers, this especially concerns banks. As a result of globalisation, banks have lost their leading position of financial agents, which has forced these institutions to engage themselves in investing. What is more, the non-banking institutions have become more active in gaining the savings available on the market. These institutions (mostly insurance companies and investment funds) are very inventive in offering various forms of lodging financial means, which constitute an alternative to the bank deposits. It is especially important for big international companies which search for considerable means to finance their current activity and investments. Their financial needs are connected to the dynamic development of the process of fusion and overtaking of the companies in individual countries and on an international scale. 